\title{
Fabrication of YSZ-based Micro Tubular SOFC Single Cell using Electrophoretic Deposition Process
}

\author{
Seung-Min $\mathrm{Yu}^{*}$ and Ki-Tae Lee $\mathrm{K}^{* * *, \dagger}$ \\ *Division of Advanced Materials Engineering, Chonbuk National University, Jeonju 54896, Korea \\ **Hydrogen and Fuel Cell Research Center, Chonbuk National University, Jeonju 54896, Korea
}

(Received July 16, 2015; Revised July 27, 2015; Accepted July 27, 2015)

\begin{abstract}
Yttria-stabilized zirconia (YSZ)-based micro tubular SOFC single cells were fabricated by electrophoretic deposition (EPD) process. Stable slurries for the EPD process were prepared by adding phosphate ester (PE) as a dispersant in order to control the $\mathrm{pH}$, conductivity, and zeta-potential. NiO-YSZ anode support, NiO-YSZ anode functional layer (AFL), and YSZ electrolyte were consecutively deposited on a graphite rod using the EPD process; materials were then co-sintered at $1400^{\circ} \mathrm{C}$ for $4 \mathrm{~h}$. The thickness of the deposited layer increased with increasing of the applied voltage and the deposition time. A YSZ-based micro tubular single cell fabricated by the EPD process exhibited a maximum power density of $0.3 \mathrm{~W} / \mathrm{cm}^{2}$ at $750^{\circ} \mathrm{C}$.
\end{abstract}

Key words : Solid oxide fuel cells, Micro tubular single cell, Electrophoretic deposition, Slurry, Dispersant

\section{Introduction}

$\mathrm{S}$ olid oxide fuel cells (SOFCs) have attracted much attention as an energy conversion technology because of their high energy conversion efficiency and low pollutant emissions. ${ }^{1,2)}$ Yttria-stabilized zirconia (YSZ) is a state-of-the-art electrolyte material for SOFCs because it has high oxygen ionic conductivity and low electronic conductivity at high temperature, and high stability in an oxidizing and reducing atmosphere.") On the other hand, the high operating temperature increases the production expense for components and leads to degradation problems. ${ }^{4)}$ Therefore, the reduction of operating temperature is a key issue. Beyond this, YSZ has a problem in that it has very low ionic conductivity at low and intermediate temperatures. The use of a thin electrolyte can reduce the ohmic resistance by reducing the length of the pass-way of oxygen ions. Generally, the use of electrode supported SOFCs is a proper approach to reducing the electrolyte thickness. However, cathode supported SOFCs have a problem in retaining strength due to low sintering temperature. On the other hand, anode supported SOFCs, due to their high strength and co-firing process, have been investigated by many researchers. ${ }^{5}$ Meanwhile, tubular SOFCs have emerged as a new type of SOFC design, one which in principle can lead to benefits of both essentially higher efficiency of planar design and easier packaging of tubular design. However, the lengthy current

\footnotetext{
${ }^{\dagger}$ Corresponding author : Ki-Tae Lee

E-mail : ktlee71@jbnu.ac.kr

Tel : +82-63-270-2290 Fax : +82-63-270-2386
}

flow pass-way of tubular type SOFCs increases the internal resistance of the cell, consequently leading to a decrease in the cell performance. Therefore, the main issue of YSZbased tubular SOFCs is to fabricate a small size device with a very thin electrolyte layer.

There are several ways to obtain a thin film electrolyte, including electrochemical vapor deposition (EVD), chemical vapor deposition (CVD), physical vapor deposition (PVD), and pulsed laser deposition (PLD). However, these processes have the disadvantage of high cost. ${ }^{6.8)}$ Electrophoretic deposition (EPD) is a very simple and inexpensive process to fabricate thin or thick films. The main advantage of EPD is that it allows the control of the thickness and shape by controlling the deposition conditions. ${ }^{9}$ Particles charged by charging agents are dispersed in a stable suspension. When a DC-electric field is applied, the charged particles move and are deposited on a support structure. ${ }^{10,11)}$

In this study, YSZ-based anode supported micro tubular SOFC single cells were fabricated using the EPD process. Various processing conditions, such as amount of charging agent, applied voltage, and deposition time, were investigated.

\section{Experimental Procedure}

Stable slurries for the anode support layer, anode functional layer (AFL), and electrolyte layer were prepared with various compositions by ball-milling. The slurry of NiO-YSZ for the anode support layer (Ni:YSZ= 60:40 vol\%) was prepared by mixing NiO (FP, Sumitomo) and YSZ (TZ-8YS, Tosoh) powders with 30 vol\% of PMMA (SUNPMMA-S100, Sunjin Chemical) as a pore former in anhydrous ethanol 
(Aldrich). Phosphate ester (PE, Ethyl acid phosphate, Johoku Chem.) was used as a dispersant. After ball-milling for $15 \mathrm{~h}$, a little more anhydrous ethanol was added and the solution was stirred in a beaker for $8 \mathrm{~h}$. Finally, $5 \mathrm{wt} \%$ polyvinyl butyral (PVB, Aldrich) was added as a binder; mixture was then stirred for $8 \mathrm{~h}$. The slurry of AFL has the same composition as the NiO-YSZ anode support layer. However, the pore former and the binder were not used. Only PE was added. After ball-milling for $15 \mathrm{~h}$, the slurry was stirred in a beaker for $8 \mathrm{~h}$. In the case of the preparation of the YSZ electrolyte layer slurry, YSZ and PE were mixed by ballmilling for $15 \mathrm{~h}$ and then stirred for $8 \mathrm{~h}$. PVB was added to the slurry to prevent cracks during the drying and sintering process. After YSZ powder, PE, and anhydrous ethanol were mixed by ball-milling for $15 \mathrm{~h}$ and stirred for $8 \mathrm{~h}, 2.5$ wt\% PVB as a binder was added and mixture was then stirred for another $8 \mathrm{~h}$.

The prepared stable slurries for the NiO-YSZ anode support, NiO-YSZ AFL, and YSZ electrolyte layer were deposited one after another on a graphite rod (Alfa Aesar, Graphite rod, $3 \mathrm{~mm}$ diameter) with a constant current and various voltages and times. The deposited samples were dried for $24 \mathrm{~h}$ at room temperature and co-sintered at $1400^{\circ} \mathrm{C}$ for $4 \mathrm{~h}$. $\mathrm{La}_{0.6} \mathrm{Sr}_{0.4} \mathrm{Co}_{0.2} \mathrm{Fe}_{0.8} \mathrm{O}_{3-8}-\mathrm{Ce}_{0.9} \mathrm{Gd}_{0.1} \mathrm{O}_{1.95}$ (LSCFGDC 50:50 wt\%, Fuel Cell Materials) cathode paste was deposited by brushing on the $\mathrm{Ce}_{0.6} \mathrm{La}_{0.4} \mathrm{O}_{2-\delta}$ (LDC) buffer layer; material was then dried for $24 \mathrm{~h}$ at room temperature, followed by firing at $1100^{\circ} \mathrm{C}$ for $2 \mathrm{~h}$. $\mathrm{Ce}_{0.6} \mathrm{La}_{0.4} \mathrm{O}_{2-\delta}$ (LDC) was used as a buffer layer between the LSCF-GDC cathode and the YSZ electrolyte to prevent reaction between
LSCF and YSZ. LDC (LDC-F, Kceracell) paste was deposited by brushing; composite was then fired at $1250^{\circ} \mathrm{C}$ for $3 \mathrm{~h}$.

$\mathrm{Au}$ was used as a current collector. Au paste was deposited on both the cathode and the anode sides, which were then fired at $800^{\circ} \mathrm{C}$ for $1 \mathrm{~h}$. Current-voltage (I-V) measurements of the single cells were performed using a fuel cell test station (SMART2, WonATech Co. Ltd, Korea) at 700 and $750^{\circ} \mathrm{C}$. Humidified $\mathrm{H}_{2}\left(\sim 3 \% \mathrm{H}_{2} \mathrm{O}\right.$ at $\left.30^{\circ} \mathrm{C}\right)$ and dry air were supplied as a fuel and oxidant with flow rates of 50 and $100 \mathrm{~mL} / \mathrm{min}$, respectively.

\section{Results and Discussion}

The $\mathrm{pH}$, electrical conductivity, and zeta-potential of each slurry, measured with various amounts of dispersant such as $\mathrm{PE}$ in order to evaluate the stability of the slurry, are shown in Fig. 1. Electrical conductivity increases with increasing $\mathrm{PE}$ content because $\mathrm{PE}$ causes a particle to be positively charged by providing the surface of a particle with protons. On the other hand, the $\mathrm{pH}$ value decreases significantly and then becomes saturated with increasing PE content. The isolated protons released from the hydroxyl group, combined with the dissociated phosphate, are absorbed on the surface of the particle as a result of the interaction between the acid and the base. ${ }^{12)}$ When the dissociation of $\mathrm{PE}$ reaches the equilibrium state, the proton absorption becomes saturated. Therefore, the $\mathrm{pH}$ value decreases sharply and then becomes saturated with increasing PE content. Meanwhile, one of most important factors affecting the stability of the slurry is the zeta-potential.

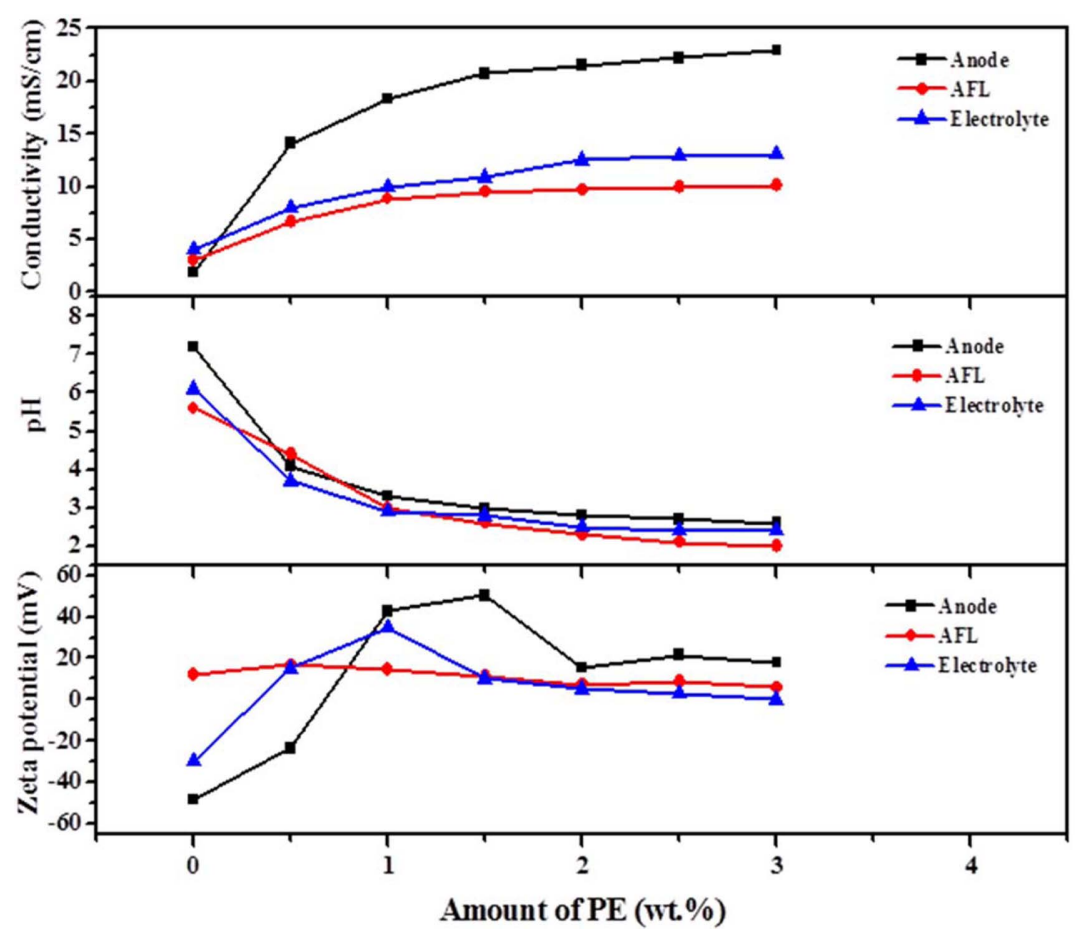

Fig. 1. (a) Conductivity, (b) pH, and (c) zeta-potential for NiO-YSZ anode support, NiO-YSZ AFL, and YSZ electrolyte slurry, respectively, as a function of the $\mathrm{PE}$ concentration. 
Table 1. Optimal Slurry Conditions for the EPD Process

\begin{tabular}{ccccc}
\hline Slurry & PE (wt\%) & PVB (wt\%) & PMMA (vol\%) & Solid loading (solute:solvent) \\
\hline NiO-YSZ anode support & 1.5 & 5 & 30 & $87: 100$ \\
NiO-YSZ AFL & 0.5 & - & - & $14: 100$ \\
YSZ electrolyte & 1 & 2.5 & - & $7: 100$ \\
\hline
\end{tabular}

When the value of the zeta-potential is higher than the isoelectric point, the particles are well dispersed. As shown in Fig. 1, the zeta-potential of the NiO-YSZ anode support had its highest value of $51 \mathrm{mV}$ at $1.5 \mathrm{wt} \%$ of $\mathrm{PE}$, which indicates that this is the most stable slurry. Similarly, the highest zeta-potential values for the AFL slurry and the YSZ electrolyte slurry were achieved at $0.5 \mathrm{wt} \%$ and $1 \mathrm{wt} \%$ of $\mathrm{PE}$, respectively. The overall optimal conditions for the slurries of the anode support, AFL, and electrolyte layers are listed in Table 1.

A well-dispersed stable slurry for each layer was deposited on the graphite rod using the EPD process. Fig. 2 shows the thickness and weight values of the deposited green body samples of the NiO-YSZ anode support layer, dried for $24 \mathrm{~h}$ at room temperature. Both the deposition weight and the thickness of the anode support increased linearly with increase of the deposition time. On the other hand, there is no significant difference between those results at 40 and 50 $\mathrm{V}$. Interestingly, both the deposition weight and the thickness of the anode support were saturated at $100 \mathrm{~s}$, despite the applied voltage.

Figure 3 shows the microstructure of the co-fired samples with various deposition times. The samples were co-sintered at $1400^{\circ} \mathrm{C}$ for $4 \mathrm{~h}$ after deposition of the anode support, AFL, and electrolyte layer one after another. Dense YSZ electrolyte was formed on the porous Ni-YSZ electrode. The thickness of the YSZ electrolyte layer gradually increased as the deposition time increased at the same voltage and current, similar to the results shown in Fig. 2. Table 2 shows the optimal deposition conditions needed to obtain crack-free rigid samples for the anode support, AFL, and electrolyte layers.

The microstructure of the fabricated micro tubular SOFC
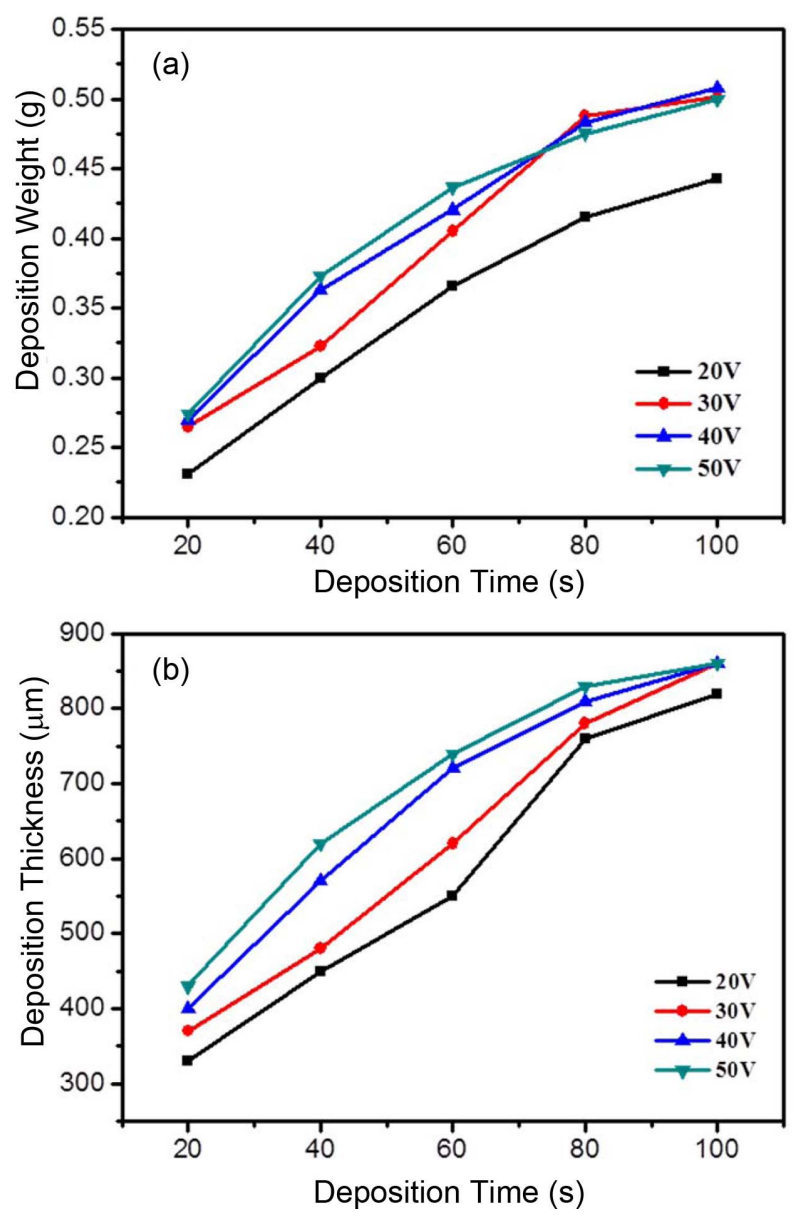

Fig. 2. The deposition (a) weight and (b) thickness of the NiO-YSZ anode support as a function of the deposition time and voltage.
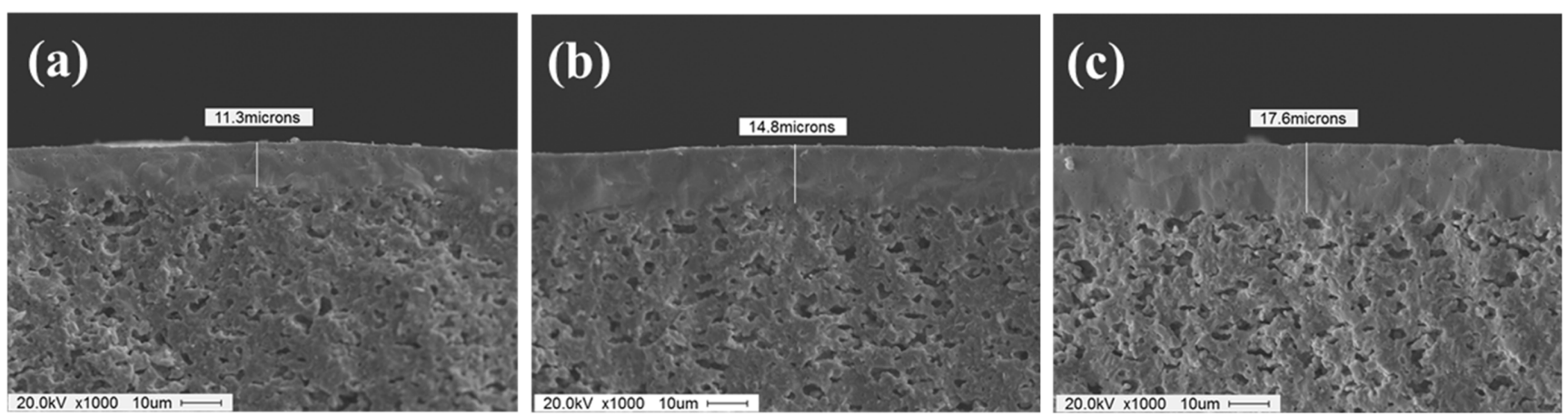

Fig. 3. Cross-sectional SEM images of the YSZ electrolyte deposited in (a) $30 \mathrm{~s}$, (b) $40 \mathrm{~s}$, and (c) $50 \mathrm{~s}$ at $40 \mathrm{~V}$ and $20 \mathrm{~mA}$, followed by sintering at $1400^{\circ} \mathrm{C}$ for $4 \mathrm{~h}$. 
Table 2. Optimal Deposition Conditions for the EPD Process

\begin{tabular}{cccc}
\hline Layer & $\begin{array}{c}\text { Voltage } \\
(\mathrm{V})\end{array}$ & $\begin{array}{c}\text { Current } \\
(\mathrm{mA})\end{array}$ & $\begin{array}{c}\text { Time } \\
(\mathrm{s})\end{array}$ \\
\hline NiO-YSZ anode support & 20 & 20 & 50 \\
NiO-YSZ AFL & 50 & 20 & 30 \\
YSZ electrolyte & 30 & 20 & 45 \\
\hline
\end{tabular}
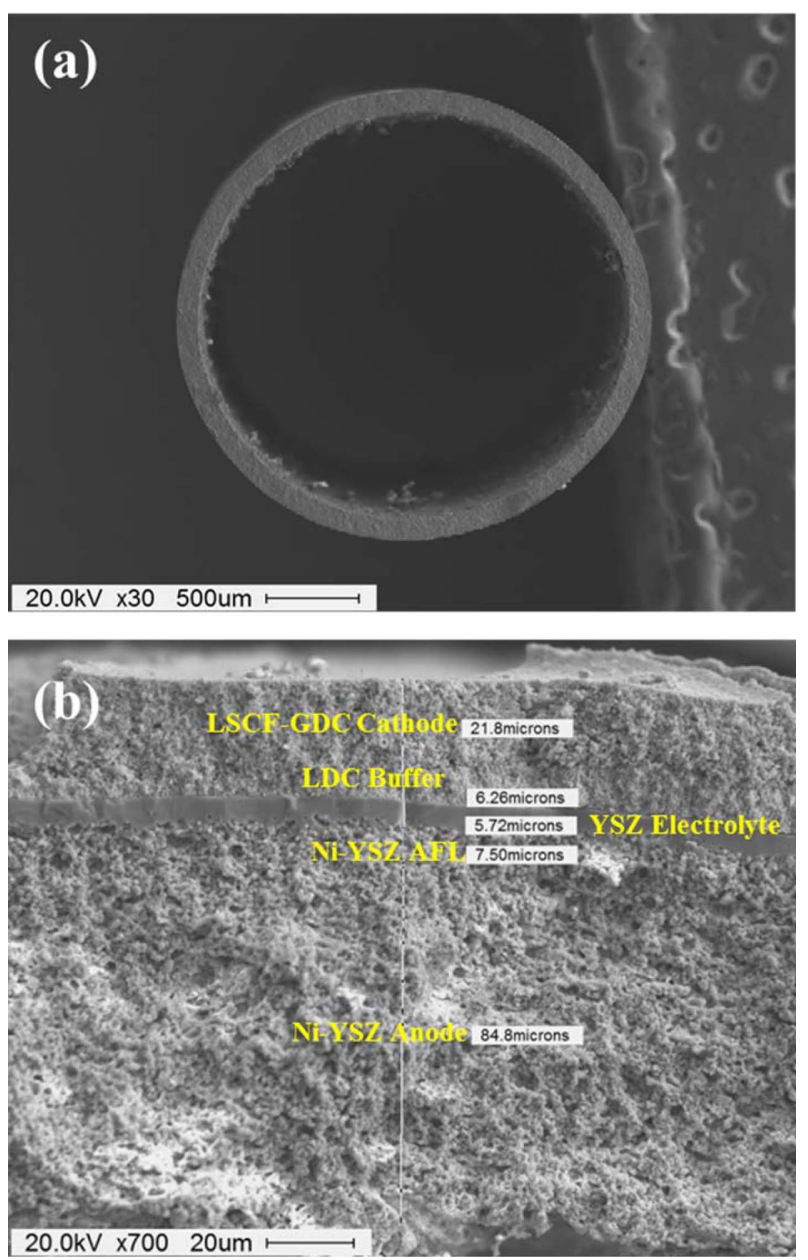

Fig. 4. Cross-sectional SEM image of the micro tubular SOFC single cell that was fabricated.

single cell with the configuration of Ni-YSZ anode support/ Ni-YSZ AFL//YSZ electrolyte//LDC buffer layer/LSCF-GDC cathode is shown in Fig. 4. The anode support, AFL, and electrolyte layers were deposited with the conditions shown in Table 2. All the layers were well attached without any delamination or cracks. A thin YSZ electrolyte with $5.7 \mu \mathrm{m}$ thickness was deposited successfully without any pin-holes. The effective electrode area was $4.6 \mathrm{~cm}^{2}$.

Current-voltage (I-V) and power density curves for the YSZ-based micro tubular SOFC single cells fabricated by the EPD process, measured at 700 and $750^{\circ} \mathrm{C}$, are shown in Fig. 5. The open-circuit voltage values at 700 and $750^{\circ} \mathrm{C}$ were typically 1.12 and $1.10 \mathrm{~V}$, respectively, which values are close to the theoretical value. This indicates that there

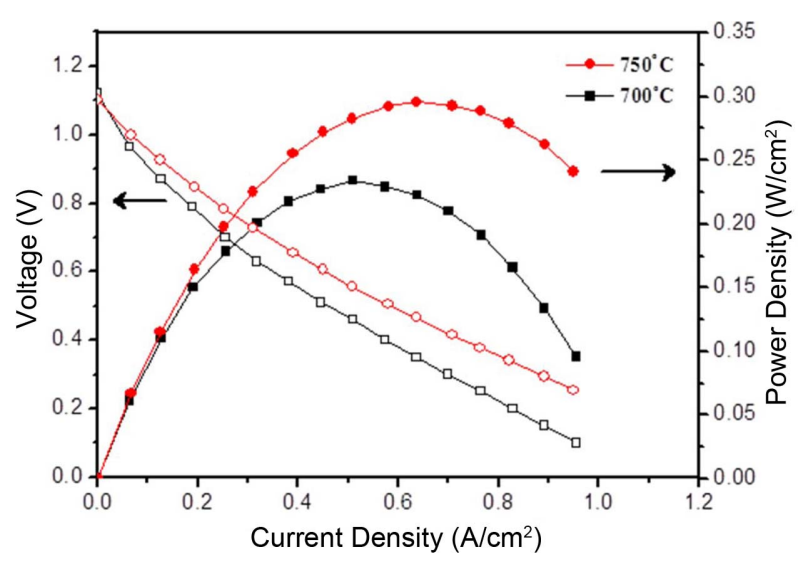

Fig. 5. Current-voltage (I-V) and power density curves for the YSZ-based micro tubular SOFC single cells fabricated by the EPD process, measured at 700 and $750^{\circ} \mathrm{C}$.

is no gas leakage through the pin-holes. The maximum power density was $0.3 \mathrm{~W} / \mathrm{cm}^{2}$ at $750^{\circ} \mathrm{C}$, which indicates considerable electrochemical performance compared to that of conventional YSZ electrolyte-based single cells in the intermediate temperature range.

\section{Conclusions}

The complicated multi-layered structure of YSZ electrolyte-based micro tubular SOFC was successfully fabricated using the EPD process. The stability of the slurry for each layer is one of the main factors influencing the EPD process; $\mathrm{PE}$ was an effective dispersion agent that can positively charge the surface of the particles. The thickness of the dense or porous layers can be controlled by manipulating the deposition time and the voltage. Finally, the YSZ electrolyte-based micro tubular SOFC fabricated using the EPD process exhibited considerable electrochemical performance at intermediate temperatures.

\section{Acknowledgments}

This research was supported by the Basic Science Research Program through the National Research Foundation of Korea (NRF), funded by the Ministry of Education (grant number: 2014R1A1A2056043). This work was also supported by a Human Resources Development program (No. 20134030200330) of the Korea Institute of Energy Technology Evaluation and Planning (KETEP) grant funded by the Korean Government Ministry of Trade, Industry and Energy.

\section{REFERENCES}

1. N.Q. Minh, "Ceramic Fuel Cells," J. Am. Ceram. Soc., 76 [3] 563-88 (1993).

2. S.C. Singhal, "Advances in Solid Oxide Fuel Cell Technol- 
ogy," Solid State Ionics, 135 [1-4] 305-13 (2000).

3. T. Talebi, B. Raissi, M. Haji, and A. Maghsoudipour, "The Role of Electrical Conductivity of Substrate on the YSZ Film Formed by EPD for Solid Oxide Fuel Cell Applications," Int. J. Hydrogen Energy, 35 [17] 9405-10 (2010).

4. S. M. Majhi, S. K. Behura, S. Bhattacharjee, B. P. Singh, T. K. Chongdar, N. M. Gokhale, and L. Besra, "Anode Supported Solid Oxide Fuel Cells (SOFC) by Electrophoretic Deposition," Int. J. Hydrogen Energy, 36 [22] 14930-35 (2011).

5. M. H. Chol, J. H. Chol, T. H. Lee, and Y. S. Yoo, "Effect of Microstructure on Mechanical and Electrical Properties in Ni-YSZ of Anode Supported SOFC," Trans. Kor. Hydrogen New Energy Soc., 22 [5] 592-98 (2011).

6. H. J. Cho and G. M. Choi, "Fabrication and Characterization of Ni-supported Solid Oxide Fuel Cell," Solid State Ionics, 180 [11-13] 792-95 (2009).

7. L. Besra, S. Zha, and M. Liu, "Preparation of NiO-YSZ/YSZ Bi-layers for Solid Oxide Fuel Cells by Electrophoretic Deposition,” J. Power Sources, 160 [1] 207-14 (2006).
8. S. W. Kim, B. H. Lee, Y. B. Son, and H. S. Song, "Preparation of Electrolyte Thin Film on NiO-YSZ Porous Substrate for Solid Oxide Fuel Cells by Electrophoretic Deposition(I)," J. Korean Ceram. Soc., 36 [5] 521-30 (1999).

9. P. Sarkar, D. De, and H. Rho, "Synthesis and Microstructural Manipulation of Ceramics by Electrophoretic Deposition," J. Mater. Sci., 39 [3] 819-23 (2004).

10. R. N. Basu, C. A. Randall, and M. J. Mayo, "Fabrication of Dense Zirconia Electrolyte Films for Tubular Solid Oxide Fuel Cells by Electrophoretic Deposition," J. Am. Ceram. Soc., 84 [1] 33-40 (2001).

11. Y. C. Wang, I. C. Leu, and M. H. Hon, Kinetics of Electrophoretic Deposition for Nanocrystalline Zinc Oxide Coatings," J. Am. Ceram. Soc., 87 [1] 84-88 (2004).

12. S. Doungdaw, T. Uchikoshi, Y. Noguchi, C. Eamchotchawalit, Y. Sakka, "Electrophoretic Deposition of Lead Zirconate Titanate (PZT) Powder from Ethanol Suspension Prepared with Phosphate Ester," Sci. Tech. Adv. Mater., 6 [8] 927-32 (2005). 